\title{
Learning Readiness by Middle School Students during Covid-19 Pandemic
}

\author{
Dadang Solihat ${ }^{1}$, Fahrus Zaman Fahly ${ }^{2}$, Cucu Suhartini ${ }^{3}$, Vina Agustina ${ }^{4}$, Jihan \\ Ananda ${ }^{5}$ \\ ${ }^{12345}$ English Education Department, Universitas Kuningan \\ \{1dadang.solihat@uniku.ac.id, ${ }^{2}$ fahruszf@uniku.ac.id, ${ }^{3}$ cusuhartini32@gmail.com, \\ 4vina.agustina@uniku.ac.id, 5jihanananda91197@gmail.com\}
}

\begin{abstract}
This study aims to determine the level of readiness of students, teachers, parents of students in learning during the Covid-19 pandemic from August to October at junior high schools (SMP) equivalent in Kuningan City, Kuningan Regency. The research method used is a one-time survey (cross-sectional survey) where data is only collected for a certain time with the aim of describing the condition of the population. The results obtained were at the student level with a sample of 174 students, 150 teachers, and 174 parents, the level of readiness of student in learning during the pandemic was $75,5 \%$, teacher's learning readiness was $77,2 \%$, and parent's learning readiness was $65,7 \%$. Therefore, the student's and parent's learning readiness during covid-19 pandemic should be increased, starts from the aspect of resources, education, and environment.
\end{abstract}

Keywords: readiness; Covid-19; learning

\section{Introduction}

The corona virus outbreak (Corona Viruses Diseases - 19) or popularly known as Covid 19 has spread very quickly throughout the world. This virus was first discovered in December 2019, to be precise in the Hunan seafood market in Wuhan City, China (Shereen, Khan, Kazmi, Bashir, \& Siddique, 2020). Covid-19 has turned the world into fear because it killed millions of people at that time. In Indonesia, this virus is a very frightening specter and has made many people experience very severe depression, especially among entrepreneurs, both small, medium and large entrepreneurs. The education sector is no exception, so learning activities have been and are still being disrupted until now, even most likely it will continue to be disrupted for the next few months. Even though the learning process really requires interaction between teachers, students, and the environment (Usman, 2006). The presence of teachers, peers or students and the learning atmosphere are important factors in the learning atmosphere. This phenomenon is a big homework for the government and education actors to find the right solution so that the implementation of learning can run well in the midst of a pandemic.

"One of the solutions set by the government is Learning from Home (BDR) in accordance with the Minister of Education and Culture Circular (SE) number 4 of 2020 which was strengthened by SE Secretary General number 15 of 2020 concerning BDR Implementation Guidelines during the Covid-19 emergency," he said. by Chaterina Head of the Ministry of Education and Culture's Regulatory Division on May 28, 2020. Teachers and students carry 
out learning activities through cyberspace or virtually. The implementation of distance learning is not done in person or physically, but is replaced by virtual meetings, namely by showing a video, presenting text, graphics and images either directly or at the same time or delayed (Griffiths, 2016). The government prepares the Teacher Room media on TVRI and other media in the implementation of learning. Teachers and Students hold occasional meetings with strict health protocols and are allowed only a few students to take turns.

Handling the impact of Covid-19 on education cannot be separated from the help of all stakeholders. The ups and downs of positive cases of Covid have a major effect on the provisions of school policies in implementing learning in the field (Aji, 2020). So that several times there were changes that made stakeholders have to find solutions and a middle way so that students did not become victims and teachers and schools could definitely carry out the process of teaching and learning activities.

From the observations of researchers during covid, various comments about Learning from Home (BDR) appeared varied. However, the tendency of parents and students and teachers to complain a lot about this BDR policy is that it still needs to be proven the level and presentation of the problem. Many have circulated on social media about complaints and problems from BDR both abroad and domestically which make it sad about the behavior of students in facing the BDR process. Not only that, the use of technology, including internet quotas, which is very important for the learning process, is often complained by parents. This should not be taken lightly because the ability to use learning technology is directly proportional to the frequent use of learning (Hung, 2016). Technology problems and the treatment of parents or families towards students are so very diverse that it is necessary to conduct a survey of this learning process, especially in junior high schools (SMP). How is the learning process for elementary and junior high school students at school and at home?

\section{Methodology}

This study uses analytical survey research, which is a survey or research that tries to explore how and why a phenomenon can occur (Notoatmojo, 2002). The cross sectional approach was chosen to obtain data in accordance with the conditions and when the study was taking place, so that data collection could be done once (Sekaran, 2014). The need for educational services related to programs, school facilities, or involvement in schools or in the community can be measured by cross sectional surveys (Creswell, 2012). Therefore, this research can be used as information in monitoring the learning readiness of junior high schools during the Covid-19 pandemic. Morissan (2014) states that population is a collection of subjects, variables, concepts, or phenomena. The population of this study were students of SMP / MTs / equivalent, teachers of SMP / MTs / equivalent, and parents / guardians of SMP / MTs / equivalent in Kuningan Regency. The sample is the object under study and is considered capable of being a representative of the entire population. In taking samples of this study, certain methods or techniques were used, so that the sample represented the population as much as possible (Notoatmodjo, 2018).

The sampling technique used in this study was cluster stratified random sampling. Cluster stratified random sampling was chosen with the intention of taking random samples to groups and not to individual subjects (Notoatmodjo, 2005). Based on data taken from kuningankab.bps.go.id, the total number of SMP and MTs students equivalent in Kuningan district is 59,056 people and 150 teachers. From each group, namely students, teachers, and 
parents, 174 students, 150 teachers and 174 parents were taken as samples with an error rate of $8 \%$ using the Slovin formula (Sugiyono, 2017).

$\mathrm{n}=$ sample size

$$
n=\frac{N}{1+N e^{2}}
$$

$\mathrm{N}=$ population size

$\mathrm{e}=$ percent leeway in inaccuracy due to tolerable sampling errors, for example $8 \%$

This research took place from August to October in Junior High Schools (SMP) equivalent in Kuningan City, Kuningan Regency. Questionnaire or a set of questions or written statements from respondents to get data (Sugiyono, 2015). In making the questionnaire, researchers were guided by the theory of Psycharis (2005) regarding 3 e-learning readiness, namely resources, education, and the environment.

\section{Result and Discussion}

The results of this study indicate the level of readiness of students, teachers, and parents in learning during Covid-19 in terms of resources, education, and the environment.

Table 1. Student Readiness for Learning during the Pandemic

\begin{tabular}{|c|c|c|c|c|c|c|c|}
\hline No. & Aspect & Student & Yes & No. & $\begin{array}{l}\text { Yes } \\
(\%)\end{array}$ & $\begin{array}{l}\text { No } \\
(\%)\end{array}$ & $\begin{array}{c}\text { Readines } \\
\text { s (\%) }\end{array}$ \\
\hline \multirow{3}{*}{1} & \multirow{3}{*}{ Resources } & You have a cellphone. & 157 & 17 & 98 & 2 & \multirow{3}{*}{81,6} \\
\hline & & You have internet quota. & 134 & 40 & 77 & 23 & \\
\hline & & Join friends when studying online. & 52 & 122 & 30.2 & 69.8 & \\
\hline \multirow{12}{*}{2} & \multirow{12}{*}{ Education } & You enjoy studying with classmates. & 167 & 7 & 96 & 4 & \multirow{12}{*}{62,3} \\
\hline & & You enjoy studying with teachers. & 171 & 3 & 98.4 & 1.6 & \\
\hline & & You enjoy studying with your parents. & 132 & 42 & 75.8 & 24.2 & \\
\hline & & $\begin{array}{l}\text { Your parent accompanies you when } \\
\text { you are studying. }\end{array}$ & 97 & 77 & 55.6 & 44.4 & \\
\hline & & $\begin{array}{l}\text { Your siblings / family members } \\
\text { accompany you while studying. }\end{array}$ & 83 & 91 & 47.6 & 52.4 & \\
\hline & & Your tutor accompanies you to study. & 27 & 147 & 15.3 & 84.7 & \\
\hline & & $\begin{array}{l}\text { The teacher always monitors your } \\
\text { learning progress. }\end{array}$ & 169 & 5 & 97.2 & 2.8 & \\
\hline & & $\begin{array}{l}\text { Teachers provide interesting lessons } \\
\text { for you. }\end{array}$ & 154 & 20 & 88.7 & 11.3 & \\
\hline & & You like studying in class. & 166 & 8 & 95.6 & 4,4 & \\
\hline & & You like studying online. & 79 & 95 & 45.6 & 54.4 & \\
\hline & & Online studying is boring. & 128 & 46 & 73.8 & 26.2 & \\
\hline & & Online learning is fun. & 51 & 123 & 29.4 & 70.6 & \\
\hline
\end{tabular}




\begin{tabular}{|c|c|c|c|c|c|c|c|}
\hline & & $\begin{array}{l}\text { Online learning makes you understand } \\
\text { the material better. }\end{array}$ & 21 & 153 & 12.1 & 87.9 & \\
\hline & & $\begin{array}{l}\text { Online learning makes you less } \\
\text { familiar with the material. }\end{array}$ & 159 & 15 & 91.5 & 8.5 & \\
\hline & & You like playing games. & 84 & 90 & 48 & 52 & \\
\hline & & $\begin{array}{l}\text { You feel stressed when studying } \\
\text { online. }\end{array}$ & 133 & 41 & 76.2 & 23.8 & \\
\hline & & $\begin{array}{l}\text { The teacher asks for the completion of } \\
\text { the assignment you are doing. }\end{array}$ & 170 & 4 & 97.6 & 2,4 & \\
\hline & & $\begin{array}{l}\text { The teacher checks the assignments } \\
\text { you are working on. }\end{array}$ & 173 & 1 & 99.6 & 0.4 & \\
\hline & & $\begin{array}{l}\text { The teacher checks your understanding } \\
\text { of the study material. }\end{array}$ & 163 & 11 & 93.5 & 6.5 & \\
\hline & & $\begin{array}{l}\text { The teacher communicates with you } \\
\text { regarding learning constraints. }\end{array}$ & 160 & 14 & 91.9 & 8.1 & \\
\hline \multirow{7}{*}{3} & \multirow{7}{*}{$\begin{array}{l}\text { Environm } \\
\text { ent }\end{array}$} & $\begin{array}{l}\text { You have a good health condition so } \\
\text { that you can do online learning. }\end{array}$ & 170 & 4 & 97.2 & 2.8 & \multirow{7}{*}{82,5} \\
\hline & & $\begin{array}{l}\text { The school provides the best service to } \\
\text { you in online learning. }\end{array}$ & 156 & 18 & 89.9 & 10,1 & \\
\hline & & School prepares hand sanitizer. & 164 & 10 & 94.4 & 5,6 & \\
\hline & & The school prepares masks. & 115 & 59 & 66.1 & 33.9 & \\
\hline & & The school prepares a face shield. & 97 & 77 & 56 & 44 & \\
\hline & & The school prepares the thermo gun. & 152 & 22 & 87.1 & 12.9 & \\
\hline & & $\begin{array}{l}\text { Home environmental conditions } \\
\text { support the learning process. }\end{array}$ & 152 & 22 & 87.1 & 12.9 & \\
\hline \multicolumn{7}{|c|}{ Average } & 75,5 \\
\hline
\end{tabular}

Based on the table above, on the resource aspect, out of 174 students, 157 (98\%) students have cellphones to study online (online), while 17 students (2\%) do not have cellphones. 134 (77\%) students have internet quota to study online, while $40(23 \%)$ students do not have internet quota. $52(30.2 \%)$ students joined friends when studying online, and $122(69.8 \%)$ students participated in learning independently. In the education aspect, as many as $167(96 \%)$ students enjoy learning with their classmates, 171 (98.4\%) students enjoy learning with their teachers, and 132 students $(75.8 \%)$ enjoy learning with their parents.

It was found that $97(55.6 \%)$ students were accompanied by their parents while studying, $83(47.6 \%)$ students were accompanied by their sibling's / family members when studying, and $27(15.3 \%)$ students were accompanied by your tutor while studying. In the learning process, $169(97.2 \%)$ students admitted that the teacher always monitored their learning progress, and $154(88.7 \%)$ students considered that the teacher provided interesting learning for them. 166 (95.6) students like to study in class, $79(45.6 \%)$ students like to study online (online).

$128(73.8 \%)$ students rated that online learning was boring, while 51 (29.4) students rated learning online as fun. For $21(12.1 \%)$ students, learning online made them understand more about the material, while 159 (91.5) students considered that learning online made them less 
understanding of the material. A number of 84 (48\%) students like to play games, and 133 $(76.2 \%)$ students feel stress when studying online (online). $170(97.6 \%)$ students admitted that the teacher asked about the completion of the assignment they were doing, $173(99.6 \%)$ students admitted that the teacher checked the assignment they were doing, 163 (93.5) students confirmed that the teacher checked their understanding of the material learning, and $160(91.9 \%)$ students confirmed that the teacher communicated with them regarding learning constraints.

Viewed from the environmental aspect, $170(97.2 \%)$ students have good health conditions so that they are able to do online learning. $164(94.4 \%)$ students admitted that their school provided the best service in online learning. 164 (94.45) students confirmed that their school prepared a hands-ionizer, masks for 115 (66.1) students, and a face shield for 97 (56\%) students. $152(87,15)$ students consider that the conditions of the home environment support the learning process. From the students' responses, it showed that the readiness level in the aspect of resources was $81 \%$, the aspect of education was $62,3 \%$, and the aspect of environment was $82,5 \%$. Overall, the level of readiness of student in learning during the pandemic was $75,5 \%$.

Table 2. Teacher Readiness in Learning during the Pandemic

\begin{tabular}{|c|c|c|c|c|c|c|c|}
\hline No. & Aspect & Teacher & Yes & No & $\begin{array}{l}\text { Yes } \\
(\%)\end{array}$ & $\begin{array}{l}\text { No } \\
(\%)\end{array}$ & $\begin{array}{l}\text { Readiness } \\
(\%)\end{array}$ \\
\hline \multirow{2}{*}{1} & \multirow{2}{*}{ Resources } & $\begin{array}{l}\text { You can operate learning support } \\
\text { devices. }\end{array}$ & 145 & 5 & 96.4 & 3,6 & \multirow{2}{*}{59} \\
\hline & & $\begin{array}{l}\text { You experience technical problems } \\
\text { during online class. }\end{array}$ & 118 & 32 & 78.6 & 21.4 & \\
\hline \multirow{11}{*}{2} & \multirow{11}{*}{ Education } & $\begin{array}{l}\text { You monitor the child's learning } \\
\text { progress. }\end{array}$ & 145 & 5 & 96.4 & 3,6 & \multirow{11}{*}{84} \\
\hline & & $\begin{array}{l}\text { You monitor children's learning } \\
\text { tools. }\end{array}$ & 139 & 11 & 92.9 & 7,1 & \\
\hline & & $\begin{array}{l}\text { You monitor children's learning } \\
\text { motivation. }\end{array}$ & 142 & 8 & 94.6 & 5,4 & \\
\hline & & $\begin{array}{l}\text { You communicate with parents in } \\
\text { monitoring the learning process from } \\
\text { home. }\end{array}$ & 115 & 35 & 76.8 & 23.2 & \\
\hline & & You prefer to teach online. & 43 & 107 & 28.6 & 71.4 & \\
\hline & & $\begin{array}{l}\text { You always prepare the material well } \\
\text { for online learning. }\end{array}$ & 145 & 5 & 96.4 & 3,6 & \\
\hline & & $\begin{array}{l}\text { You prepare interesting lessons for } \\
\text { students. }\end{array}$ & 147 & 3 & 98 & 2 & \\
\hline & & $\begin{array}{l}\text { Teaching children to learn online } \\
\text { makes you stressful. }\end{array}$ & 86 & 64 & 57.1 & 42.9 & \\
\hline & & $\begin{array}{l}\text { You ask for the completion of a task } \\
\text { the child was doing. }\end{array}$ & 142 & 8 & 94.6 & 5,4 & \\
\hline & & $\begin{array}{l}\text { You check the work the child is } \\
\text { doing. }\end{array}$ & 147 & 3 & 98.2 & 1.8 & \\
\hline & & $\begin{array}{l}\text { You check the child's understanding } \\
\text { of the learning material. }\end{array}$ & 139 & 11 & 92.9 & 7,1 & \\
\hline
\end{tabular}




\begin{tabular}{|c|c|c|c|c|c|c|c|}
\hline & & $\begin{array}{l}\text { You communicate with children } \\
\text { about learning problems. }\end{array}$ & 137 & 13 & 91.1 & 8.9 & \\
\hline & & $\begin{array}{l}\text { You consult with parents regarding } \\
\text { children's learning barriers. }\end{array}$ & 118 & 32 & 78.6 & 21.4 & \\
\hline & & $\begin{array}{l}\text { You monitor children's learning } \\
\text { activities. }\end{array}$ & 139 & 11 & 92.9 & 7,1 & \\
\hline \multirow{7}{*}{3} & \multirow{7}{*}{ Environment } & $\begin{array}{l}\text { You have a good health condition so } \\
\text { that you can do online learning. }\end{array}$ & 142 & 8 & 94.6 & 5,4 & \multirow{7}{*}{89} \\
\hline & & $\begin{array}{l}\text { The school provides the best service } \\
\text { for you in online learning. }\end{array}$ & 129 & 21 & 85.7 & 14.3 & \\
\hline & & School prepares handsanitizer. & 145 & 5 & 96.4 & 3,6 & \\
\hline & & The school prepares masks. & 131 & 19 & 87.5 & 12.5 & \\
\hline & & The school prepares a face shield. & 110 & 40 & 73.2 & 26.8 & \\
\hline & & The school prepares the thermogun. & 147 & 3 & 98.2 & 1.8 & \\
\hline & & $\begin{array}{l}\text { Home environment conditions } \\
\text { support the learning process online. }\end{array}$ & 131 & 19 & 87.5 & 12.5 & \\
\hline \multicolumn{7}{|c|}{ Average } & 77,2 \\
\hline
\end{tabular}

Of the 150 teachers, in the aspect of resource, it was found that $145(96.4 \%)$ of the teachers were able to operate online learning support devices, and $118(78.6 \%)$ of the teachers often encountered technical problems when online learning took place. In the education aspect, 145 (96.4\%) teachers monitor children's learning development, 139 (92.9\%) teachers monitor children's learning facilities, 142 (94.6\%) teachers monitor children's learning motivation, and $115(76.8 \%))$ the teacher communicates with the parents in monitoring the learning process from home. In addition, $43(28.6 \%)$ teachers prefer to teach online, $145(96.4 \%)$ teachers always prepare well material for online learning, and 147 (98\%) teachers prepare learning of interest to students. For $86(57.1 \%)$ teachers, teaching children to learn online made them stressful. However, $142(94.6 \%)$ teachers asked about the completion of tasks that were done by children, $147(98.2 \%)$ teachers checked the tasks done by children, and $139(92.9 \%)$ teachers checked children's understanding of learning materials.

As many as 137 (91.1\%) teachers admitted that they communicated with children related to learning problems, $118(78.6 \%)$ teachers admitted that they consulted their parents regarding children's learning barriers, and $139(92.9 \%)$ teachers monitored their activities. child learning. In the environmental aspect, $142(94.6 \%)$ teachers have a good health condition so that they are able to do online learning, $129(85.75 \%)$ teachers think that the school provides the best service to you in learning online (online) . $145(96.4 \%)$ teachers admitted that the school prepared hands-on filters, masks for $131(87.5 \%)$ teachers, face shields for 110 (73.2\%) teachers, and thermogun for $147(98.2 \%)$ teachers. The condition of the home environment also supports the online learning process for $131(87.5 \%)$ teachers. From the teachers' responses, it showed that the readiness level in the aspect of resources was $59 \%$, the aspect of education was $84 \%$, and the aspect of environment was $89 \%$. Overall, the level of readiness of teacher in learning during the pandemic was $77,2 \%$. 
Table 3. Readiness of Parents for Learning during the Pandemic

\begin{tabular}{|c|c|c|c|c|c|c|c|}
\hline No. & Aspect & Parents & Yes & No & Yes $(\%)$ & No $(\%)$ & $\begin{array}{l}\text { Readiness } \\
(\%)\end{array}$ \\
\hline \multirow{6}{*}{1} & \multirow{6}{*}{ Resources } & $\begin{array}{l}\text { You prepare your child's } \\
\text { cellphone. }\end{array}$ & 167 & 7 & 96.2 & 3.8 & \multirow{6}{*}{65,1} \\
\hline & & $\begin{array}{l}\text { You have internet quota for } \\
\text { your children. }\end{array}$ & 143 & 31 & 82 & 18 & \\
\hline & & $\begin{array}{l}\text { You let your child studying } \\
\text { with friends while online } \\
\text { learning. }\end{array}$ & 80 & 94 & 45.9 & 54.1 & \\
\hline & & $\begin{array}{l}\text { You spend more money on } \\
\text { children's schools during } \\
\text { pandemic. }\end{array}$ & 139 & 35 & 79.7 & 20.3 & \\
\hline & & Both parents work. & 80 & 94 & 45.9 & 54.1 & \\
\hline & & One parent works. & 147 & 27 & 84.4 & 15.6 & \\
\hline \multirow{11}{*}{2} & \multirow{11}{*}{ Education } & $\begin{array}{l}\text { You don't master the child } \\
\text { material. }\end{array}$ & 111 & 63 & 63.9 & 36.1 & \multirow{11}{*}{56,6} \\
\hline & & $\begin{array}{l}\text { Your child can understand } \\
\text { the material well during the } \\
\text { learning process at home. }\end{array}$ & 89 & 85 & 51.1 & 48.9 & \\
\hline & & $\begin{array}{l}\text { No one accompanies the } \\
\text { child to learn. }\end{array}$ & 80 & 94 & 45.9 & 54.1 & \\
\hline & & $\begin{array}{l}\text { Your child is self-sufficient } \\
\text { and does not need } \\
\text { assistance. }\end{array}$ & 113 & 61 & 64.7 & 35.3 & \\
\hline & & $\begin{array}{l}\text { You need other people } \\
\text { (other family members / } \\
\text { tutors / others) to assist the } \\
\text { children in learning. }\end{array}$ & 81 & 93 & 46.6 & 53.4 & \\
\hline & & $\begin{array}{l}\text { At any time, you can } \\
\text { accompany the child to } \\
\text { study. }\end{array}$ & 55 & 119 & 31.6 & 68.4 & \\
\hline & & $\begin{array}{l}\text { Teaching children to study } \\
\text { at home makes } \\
\text { you stressful. }\end{array}$ & 113 & 61 & 64.7 & 35.3 & \\
\hline & & $\begin{array}{l}\text { You ask for the completion } \\
\text { of a task the child was } \\
\text { doing. }\end{array}$ & 162 & 12 & 93.2 & 6.8 & \\
\hline & & $\begin{array}{l}\text { You check the work the } \\
\text { child is doing. }\end{array}$ & 133 & 41 & 76.7 & 23.3 & \\
\hline & & $\begin{array}{l}\text { You check the child's } \\
\text { understanding of the } \\
\text { learning material. }\end{array}$ & 127 & 47 & 72.9 & 27.1 & \\
\hline & & $\begin{array}{l}\text { You communicate with } \\
\text { children about learning } \\
\text { problems. }\end{array}$ & 153 & 21 & 88 & 12 & \\
\hline
\end{tabular}




\begin{tabular}{|c|c|c|c|c|c|c|c|}
\hline & & $\begin{array}{l}\text { You consult with the } \\
\text { teacher regarding children's } \\
\text { learning barriers. }\end{array}$ & 47 & 127 & 27.1 & 72.9 & \\
\hline & & $\begin{array}{l}\text { You don't monitor } \\
\text { children's learning } \\
\text { activities. }\end{array}$ & 42 & 132 & 24.1 & 75.9 & \\
\hline & & $\begin{array}{l}\text { Schools / teachers } \\
\text { communicate with parents } \\
\text { in monitoring the learning } \\
\text { process from home. }\end{array}$ & 99 & 75 & 57.1 & 42.9 & \\
\hline & & $\begin{array}{l}\text { The learning development } \\
\text { of children is always } \\
\text { monitored by the school / } \\
\text { teacher. }\end{array}$ & 144 & 30 & 82.7 & 17.3 & \\
\hline & & $\begin{array}{l}\text { Children's learning } \\
\text { facilities are monitored by } \\
\text { the school / teacher. }\end{array}$ & 128 & 46 & 73.7 & 26.3 & \\
\hline & & $\begin{array}{l}\text { Schools / teachers monitor } \\
\text { children's learning } \\
\text { motivation. }\end{array}$ & 140 & 34 & 80.5 & 19.5 & \\
\hline & & $\begin{array}{l}\text { You allow face-to-face } \\
\text { Teaching and Learning } \\
\text { Activities. }\end{array}$ & 164 & 10 & 94 & 6 & \\
\hline \multirow{6}{*}{3} & \multirow{6}{*}{ Environment } & $\begin{array}{l}\text { The school provides the } \\
\text { best service for you in } \\
\text { online learning. }\end{array}$ & 145 & 29 & 83.5 & 16.5 & \multirow{6}{*}{75,1} \\
\hline & & $\begin{array}{l}\text { School prepares hand } \\
\text { sanitizer. }\end{array}$ & 167 & 7 & 97.7 & 2,3 & \\
\hline & & The school prepares masks. & 99 & 75 & 56.9 & 43.1 & \\
\hline & & $\begin{array}{l}\text { The school prepares a face } \\
\text { shield. }\end{array}$ & 73 & 101 & 42.1 & 57.9 & \\
\hline & & $\begin{array}{l}\text { The school prepares } \\
\text { the thermo gun. }\end{array}$ & 147 & 27 & 84.2 & 15.8 & \\
\hline & & $\begin{array}{l}\text { Home environment } \\
\text { conditions support } \\
\text { children's learning process. }\end{array}$ & 150 & 24 & 86.5 & 13.5 & \\
\hline
\end{tabular}

\section{Average}

65,7

Based on data collected from 174 students' parents, on the resource aspect it was found that $167(96.2 \%)$ parents prepared cellphones for their children to study online, and $143(82 \%)$ parents prepared internet quotas for learning. online for their child. Meanwhile, $80(45.9 \%)$ parents let their children join friends when studying online, and $139(79.7 \%)$ parents admitted that they spent more money on children's schools during the pandemic. $80(45.9 \%)$ parents admitted that both parents / guardians worked, while $147(84.4 \%)$ parents admitted that one parent / guardian worked. From the aspect of education, as many as $111(63.9 \%)$ parents did not master children's material. $89(51.1 \%)$ parents think that their child can understand the material well during the learning process at home. 80 (45.9\%) parents admit that no one accompanies their child to study. $113(64.7 \%)$ parents considered that their child was quite independent and did not need assistance. 
However, 81 (46.6\%) parents need other people (other family members / tutors / others) to assist their children in learning. As many as $55(31.6 \%)$ parents at any time can accompany their children to learn. $113(64.7 \%)$ parents admitted that teaching children to study at home made them stressful, $162(93.2 \%)$ parents asked about completing tasks that were done by children, 133 (76.7\%) parents checked the tasks that were done by children , $127(72.9 \%)$ parents check children's understanding of learning materials, 153 (88\%) parents communicate with children regarding learning constraints, $47(27.1 \%)$ parents consult with teachers regarding children's learning barriers, and only $42(24.1 \%)$ parents who did not monitor their children's learning activities.

In addition, $99(57.1 \%)$ parents admitted that the school / teacher communicated with parents in monitoring the learning process from home, 144 (82.7\%) parents considered that the child's learning development was always monitored by the school / teacher. According to 128 (73.7\%) parents, children's learning facilities are monitored by the school / teacher, and 140 (80.5\%) parents confirm that the school / teacher monitors children's learning motivation. 164 (94\%) parents allowed face-to-face Teaching and Learning Activities. In the environmental aspect, $145(83.5 \%)$ parents assess that schools provide the best services in online learning. As many as $167(97.7 \%)$ parents know that the school prepares a hand hygiene kit, $99(56.9 \%)$ knows that the school prepares masks, 73 (42.1\%) parents know that the school is preparing a face shield, and $147(84.2 \%) \%)$ parents know that the school has prepared a thermos guard. For $150(86.5 \%)$ parents, the condition of the home environment supports the child's learning process. From the parents' responses, it showed that the readiness level in the aspect of resources was $65,1 \%$, the aspect of education was $56,6 \%$, and the aspect of environment was $75,1 \%$. Overall, the level of readiness of parents in learning during the pandemic was $65,7 \%$.

\section{Conclusion}

Based on the description of the results obtained from the answers of students, teachers, and parents, it shows that from the aspect of resources, the student's learning readiness was $81 \%$, teacher's learning readiness was $59 \%$, and parent's learning readiness was $65 \%$. Viewed from the aspect of education, student's learning readiness was $62,3 \%$, teacher's learning readiness was $84 \%$, and parent's learning readiness was $56,6 \%$. Meanwhile, from the aspect of environment, student's learning readiness was $82,5 \%$, teacher's learning readiness was $89 \%$, and parent's learning readiness was $75,1 \%$. Overall, the level of readiness of student in learning during the pandemic was $75,5 \%$, teacher's learning readiness was $77,2 \%$, and parent's learning readiness was $65,7 \%$. Therefore, the student's and parent's learning readiness should be increased, started from the aspect of resources, education, and environment.

\section{References}

[1] Aji, R. H. S. (2020). Dampak Covid-19 pada Pendidikan di Indonesia: Sekolah, Keterampilan, dan Proses Pembelajaran. Jurnal Sosial \& Budaya Syar-i Vol. 7 No. 5. pp. 395-402, DOI: 10.15408/sjsbs.v7i5.15314 
[2] Badan Pusat Statistik Kabupaten 2020 . https://kuningankab.bps.go.id/statictable/2020/01/05/41/banyaknya-sekolah-murid-guru-dan-rasiomurid-guru-smp-dan-mts-di-kabupaten-kuningan-2020.html

[3] Creswell, J. W. (2012). Research Design Pendekatan Kualitatif, Kuantitatif, dan Mixed. Yogyakarta: Pustaka Pelajar

[4] Griffiths, B. (2016). A Faculty's Approach to Distance Learning Standardization. Teaching and Learning in Nursing, 11(4), 157-162. https://doi.org/10.1016/j.teln.2016.04.004

[5] Hung, M. L., Chou, C., Chen, C. H., Own. Z. Y. (2010). Learner readiness for online learning: Scale development and student perception. Computers \& Education, 55(2010), 1080-1090. Doi:10.1016/j.compedu.2020.05.004.

[6] Morissan, M. (2014). Metode Penelitian Survei. Jakarta: Kencana

[7] Notoatmodjo, S. (2018) Notoatmod. Metodologi Penelitian Kesehatan. Jakarta: PT Rineka Cipta

[8] Notoatmodjo, S. (2005). Metodologi Penelitian Kesehatan. Jakarta: PT Rineka Cipta

[9] Notoatmodjo, S. (2002). Metodologi Penelitian Kesehatan. Jakarta: PT Rineka Cipta

[10] Psycharis, S. (2005). Presumtions and actions affecting an e-learnng adoption by educational system implementation using virtual network. http://www.eurodl.org/material/contrib/2005/Sarantos_Psycharis.htm. Retrived November 21, 2020

[11] Sekaran, U. (2014). Metodologi Penelitian untuk Bisnis. Jakarta: Salemba Empat

[12] Shereen, M. A, Khan, S., Kazmi, A., Bashir, N., \& Siddique, R. (2020). COVID-19 infection: Origin, transmission, and characteristics of human coronaviruses. Journal of Advanced Research, S2090123220300540. https://doi.org/10.1016/j.jare.2020.03.005.

[13] Sugiyono. (2017). Metode Penelitian Pendidikan (Pendekatan Kuantitatif, Kualitatif, dan R\&D). Bandung: Alfabeta

[14] Sugiyono. (2015). Metode Penelitian Pendidikan (Pendekatan Kuantitatif, Kualitatif, dan R\&D). Bandung: Alfabeta

[15] Usman, M. U (2006). Menjadi Guru Profesional. Bandung: Remaja Rosdakarya 